\title{
Interment: Re-framing the Death of the Red Location Museum Building (2006 - 2013)
}

\author{
MICHELLE SMITH \\ University of Fort Hare
}

The design and construction of the Red Location Precinct was the culmination of a national architectural competition, the first outcome of which was the Red Location Museum. Situated in New Brighton, Port Elizabeth, the materiality of the township impressed itself on the factory-styled museum building. However, the residents of New Brighton were not unanimously in favour of the building of a cultural precinct and museum, and through a number of protests, closed down the museum. Renaming it 'a house for dead people', the community began to disassemble the museum building. The museum is now a ruin, its frame decomposing. Rather than staging the porousness between an inside and an outside of the museum - and between the past and present, the real and the simulated, the living and the dead - as a problem to be worked out in dialogue, the museum has, by framing the struggle against apartheid commemoratively, incorporated the residents of New Brighton into what is called here a 'mortificationary complex'. This article elaborates the concept of the frame as it works through the displays within the Red Location Museum and its building, reframed by Simon Gush's installation, Red. Juxtaposing Red and the Red Location Museum allows the affects and effects of this artwork to seep beyond the confines of the events with which it explicitly grapples. Through the concept of the frame, this encounter asks that we rethink the materiality of the photograph, the commemoration of the struggle against apartheid, and the ways in which death marks the sights and sites of public history in museums after 1994.

As the story goes, in 1990 at the Mercedes-Benz factory in East London, in the midst of protracted and tumultuous labour disputes - including a wild-cat, sleep-in strike that saw the removal of strikers by the police and approximately 500 strikers being dismissed - workers assembled a top-of-the-range red 500SE for Nelson Mandela, which they delivered to him after his release from prison. ${ }^{1}$ Mercedes-Benz provided the parts for the car, but the initiative for the Mandela car came from the workers, who chose the model and colour, and assembled it afterhours, without fault and without additional pay. It is this set of historical events that artist Simon Gush takes as the subject for his installation, Red, a 'speculative reconstruction' of the Mandela car,

1 A number of people have generously read and provided comments during different stages of the writing of this article. In particular, my thanks go to the editors of this volume, Gary Minkley, Helena Pohlandt-McCormick, Leslie Witz and John Mowitt, as well as to Ross Truscott, Henriette Gunkel and Qadri Ismail. Feedback received from the two anonymous reviewers enriched my argument in important ways too - thank you. 
accompanied by a documentary film made with James Cairns and strike uniforms designed by Mokotjo Mohulo. ${ }^{2}$

After being shown at the Goethe Institute gallery in Johannesburg in 2014, Red was exhibited in 2015 at the Ann Bryant, a large East London home that has been converted into an art gallery. This was the same venue for the workshop 'Red Assembly: Time and Work', which asked participants to think about 'the question of what it would mean to place art at the centre of a historical reading. ${ }^{3}$ I would like here to push this call, perhaps even stretch it; to ask what it would mean to place this artwork at the centre of an historical reading beyond its immediate field of reference. In specific, I place Red alongside - and within the same frame, a concept I return to below - exhibitions of struggle history in the now closed Red Location Museum in New Brighton, Port Elizabeth.

The naming of the Red Location Museum as a 'house for dead people'4 signals two aspects of the museum; its building - the architecture - and that which it holds and displays inside. The objects that proliferate inside the museum walls are particular kinds of photographs, which as I argue below, are more than mere representations when you consider the inside and outside, the location and displays and the excess of the photograph as impacting on each other.

The history of New Brighton has been burdened with death and struggle, from its development in the early twentieth century (which was rationalised by a colonial government as a way of curbing the spread of the bubonic plaque), through the struggle against apartheid, to the current residents' continuing struggle against poverty and exploitation. ${ }^{5}$ In what follows, I read the mobilisation of images in the exhibitions of the Red Location Museum and their visualisation of death. The argument is that, at the Red Location Museum, death frames the site of public history and the narrative of the struggle against apartheid, which becomes the display of suffering. This argument is made with reference to a particular photograph that forms a part of the display of the Langa Massacre of $1985,{ }^{6}$ but which comes to frame the other exhibitions in the museum. Indeed, it comes to incorporate the 'community' outside the museum as well. I pay attention here to how 'the photograph' comes to represent the death of the black body and produce, as an unintended effect, the mortification of the residents of this township. If death and struggle preside over and run through the history of New Brighton, then so too does a struggle against mortification.

Similarly, death is figured in Red through the invocation of mourning as a condition of the post-apartheid. In the narrative of the documentary, the workers present Mandela with a car the colour of which symbolises, for him, the lives lost during the struggle. The car stands in for those who have been lost in the struggle, and it was, as

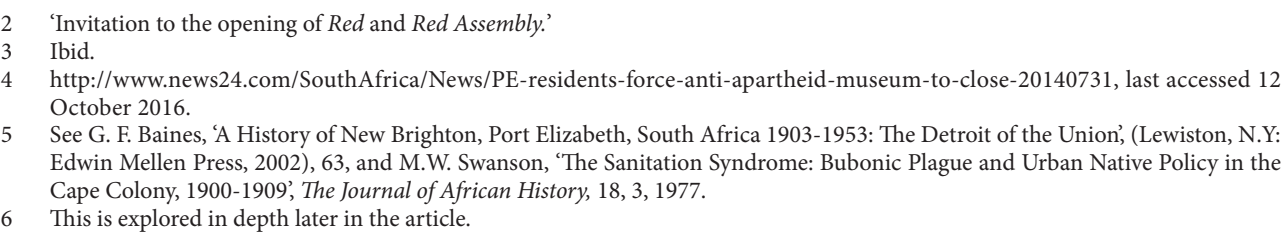

5 See G. F. Baines, 'A History of New Brighton, Port Elizabeth, South Africa 1903-1953: The Detroit of the Union', (Lewiston, N.Y: Edwin Mellen Press, 2002), 63, and M.W. Swanson, 'The Sanitation Syndrome: Bubonic Plague and Urban Native Policy in the Cape Colony, 1900-1909', The Journal of African History, 18, 3, 1977.

This is explored in depth later in the article. 
Phillip Groom explains, carried off the assembly line - like a coffin - the assembly of the car as much a work of mourning as a labour of love. ${ }^{7}$ Red presents this notion as a question to think about rather than a claim to be affirmed. Juxtaposing Red and the Red Location Museum, I want to suggest, allows the affects and effects of this artwork to seep beyond the confines of the events with which it explicitly grapples.

\section{'A house for dead people'}

In 1998, very soon after the demise of the apartheid government and the 1980s period of protest and activism, the administration and finance committee of the City Council decided that the design and construction of the Red Location Precinct should be the outcome of a national architectural competition. Styled on the Apartheid Museum, the precinct would reconstruct or restore the existing original corrugated iron housing and entail the building of an Art Gallery, a Centre for Creative Arts, a market, a library, a hall and conference centre. ${ }^{8}$ The winners of this competition - Noero Wolff Architects, established in Johannesburg and currently based in Cape Town - were announced on 10 December 1998. Several years later, in 2003, construction began on the Red Location Museum, which became accessible to the public in November 2006. The architectural design of the Red Location Museum was featured in an exhibition at the Museum of Modern Art in New York in 2010. ${ }^{9}$ When this was announced to the public, Noero was quoted as saying, 'What is important to stress is that this is not just about doing good things for poor people, but giving poor people world-class architecture too. ${ }^{10}$ At first, this utterance is empty of meaning, at least with regard to what this means to the people of New Brighton in any practical sense. It does draw attention to the fact that the architectural design of the museum is rendered novel on account of its location. What is important here is that the museum's responsibility entailed not only a curatorial narrative, but also an intense proximity between the site of the museum and the residents of New Brighton. ${ }^{11}$ Furthermore, in the building of

7 Here, one could also cite the 500 workers who were dismissed at the Mercedes-Benz factory, their lives, or livelihoods lost in a long history of struggle. Now that Mandela has passed away, he, too, is one of the mourned. See Gush and Cairns, Red, specifically the interview with Phillip Groom.

8 Cultural Precinct: Phase 2, Business Plan, 12.

9 An extensive architectural project, the plan for the Cultural Precinct was laid out in two phases. Phase I included the Museum, Olaf Palme Avenue - which is the tarred road running along the front of the museum, and between it and the library - and Pelip Housing, which is the housing provided for those whose shacks had been cleared to create 'space' for the precinct. Phase II of the precinct plan comprises the art gallery; the library and library archive; a commercial complex; subsidy housing units and a commercial, multi-storey housing development; the conversion of the Old Beer Hall into a backpackers hostel; the redevelopment of the open-air theatre into a weather-proof structure; the preservation of the four remaining historic Red Location buildings, the redevelopment of Skyman's store into an education centre; the building of an open-air, public sculpture and the creation of a 'heritage walk' from the precinct to Emlotheni; the restoration of the New Brighton Station; the creation of dedicated and safe parking; the creation of a precinct shop and office, and other facilities for precinct staff. The point here is that the Red Location Museum building itself was significant from the very start of the project. From its visual effects on the landscape and its spatiality, to the symbolism of its structure, the apparatus was always already at work, from the laying of the first brick, attempting to put in place the museum's temporal logic.

10 B. Hollands, 'New Accolade for Bay Museum', Weekend Post, 31 July 2010.

11 This also illuminates a discourse of paternalism, which in its colonial iteration, is mostly absent in the museum. Despite and perhaps because of the protest and rejection of this project by the residents, decisions about their well-being are made for them on the assumption that they themselves do not know what is 'good' for them. What is masked by this notion of doing good for the poor is the attempt to act on behalf of the 'poor' black body. 
the museum precinct 'the materiality of the township was deployed as the conceptual starting point' for Noero Wolff Architects. ${ }^{12}$

The museum is not situated very far from the road that leads into New Brighton after you have taken the Deal Party turnoff from the highway. ${ }^{13}$ After driving along a neglected road, you very soon reach the sign instructing you to turn right in the direction of the museum. The intention is to have the sign to the museum, and the museum to which it directs visitors, form part of the New Brighton landscape. The museum, and the rest of the precinct, however, commandeers the space; its grandeur is in stark contrast to the dwellings around it, in which it assumes a place. A photograph in an annex in the museum's second-phase business plan shows an attempt to present a view of the building from one of the untarred, littered side streets which joins onto the perfectly maintained, cemented area around the museum structure and its neighbouring precinct buildings; a scene that shows life proceeding, rather unaffected, for the residents, with children wandering around, two women sitting next to each other doing their laundry, and some wandering animals. Towering above this scene is the 'saw-tooth roof' of the factory-styled building of the Red Location Museum. ${ }^{14}$

It is from the corrugated iron structures, mentioned above, which the project sought to restore and reconstruct, that the Red Location takes its name. The structures come from 1903 when they were used during the South African War (specifically in Uitenhage and De Aar). Afterwards, corrugated iron was used to erect shack dwellings in the area where the Red Location is situated..$^{15}$ The rust that formed on the corrugated iron gave the area its name. There are four such structures used in the museum. In 2005, a proposal was written, as part of the phased planning of the precinct, suggesting ways of preserving them. One became an installation, lodged outside the art gallery of the cultural precinct. Inside the museum these structures are reproduced, although different in scale - they reach to the ceiling of the museum building - as memory boxes (six metres long and wide, 12 metres high), 'inspired by the boxes that migrant workers used to accommodate their prized possessions when separated from their families. ${ }^{16}$ To recreate the rusty red colour of the old shack dwellings, these memory boxes were made with corten or weathered steel, which has a rust-like appearance.

Entering one of the 12 structures produces the sensation of being 'inside' a shack, or what is meant to resemble the homes of the residents around the precinct, with the

12 N. Murray and L. Witz, 'From eviction to commission in Lwandle: Stories of museums, design and urban development', presented at Wits City Institute Seminar Series for Semester Two, Seminar 1 of 15, 2015, 8.

13 'Location' or site is significant to the conceptualisation of the apartheid museum after 1994, as we also see with the Apartheid Museum at Gold Reef City and the Hector Pieterson Museum in Soweto. The Apartheid Museum is situated where a former mine operated, along with other establishments forming the Gold Reef City theme park. (265) The Hector Pieterson Museum is situated where the young student died, shot by apartheid police, on 16 June 1976 during the Soweto student uprising. The Hector Pieterson Museum is a red-brick building 'reflecting the materials used in Soweto and many South African townships'. (D. Newbury, "Lest we forget": Photography and the Presentation of History at the Apartheid Museum, Gold Reef City, and the Hector Pieterson Museum, Soweto, Visual Communications, 4, 3, October 2005, 259-295.) The Red Location Museum is situated at 'the oldest surviving "location", or area designated exclusively for African living, in Port Elizabeth, and probably South Africa' and 'was a national centre of anti-apartheid activism, and has a long history of such resistance.' (Cultural Precinct Phase 2: Business Plan, 15-16.)

14 See image number 8 on the following website, http://www.noeroarchitects.com/red-location-museum/, last accessed 3 December 2016.

15 Cultural Precinct: Phase 2 Business Plan

16 http://www.freewebs.com/redlocationmuseum/, last accessed 14 October 2016. 
'inside' of the other memory boxes 'offering a set of different memories of struggle in South Africa. ${ }^{17}$ Yet the structures outside the museum, the homes of the New Brighton residents, can and do quite literally corrode, as they are precariously vulnerable to the elements. The worker, as an oppressed figure of the struggle, further informs the idea of this museum spatially and materially in the very design and structure of the factory-like building of the museum. These two types of structures, the shack and the factory, come to represent a 'home aesthetic'18 of the museum 'intended to make associations between community and workers. ${ }^{19}$

Upon the completion of the Red Location Museum building in 2005, a year before it opened to the 'public', the residents living in the area surrounding the museum and precinct structure, dumped 'human waste buckets' and burned tyres on the front steps to the building. ${ }^{20} \mathrm{~A}$ number of residents were angered by the amount of money spent on the cultural precinct, of which more will be said below, instead of being spent on the improvement of their own living conditions. ${ }^{21}$ It also seems obvious that this should not be a choice in the first place, that decent living conditions and a museum should both be possible for the people living in the area. These actions were a pointed response to the manifestation of Port Elizabeth City Council's intentions of celebrating and commemorating a history of struggle and those who died in New Brighton for the end of oppression. This reaction to the museum is in stark contrast to Professor and Head of the Institute for African Renaissance Studies and the University of South Africa Vuyisile Msila's perceptions of the work that the museum does. The museum, for him, has a liberatory function. He writes that the Red Location Museum's use of memory 'is linked to freedom from bondage', that the representation of traumatic memory and experience can yield a positive result. ${ }^{22}$ If this is the supposed function of museums in general and the Red Location Museum in particular, then we must wonder about whether the residents' resistance and protest is not motivated by more than the need for basic services. The Red Location Museum and the precinct have been closed since October 2013 following more protests by the residents of New Brighton against the establishment of a 'house for dead people.23 This reveals a tension between the museum's representation of the struggle against apartheid in the past and the performance of protest on its doorstep by people for whom this 'struggle' is very much present. This outside performance of what is inside

17 http://www.freewebs.com/redlocationmuseum/, last accessed 14 October 2016.

18 N. Murray and L. Witz, 'From eviction to commission in Lwandle: Stories of Museums, Design and Urban Development', presented at Wits City Institute Seminar Series for Semester Two, Seminar 1 of 15, 2015, 9.

19 Ibid

20 C. Du Preez, 'The Role of Architecture in South Africa's Unequal Society: The Closure of Red Location Museum as a Case Study', 2014. Written to initiate conversation about the role of architecture in South Africa at the International Union of Architects World Congress in Durban, South Africa, 2014.

21 The 1997 Administration and Finance committee of the City Council of Port Elizabeth decided to use R52-million to fund seven projects, one of which is the cultural centre in the Red Location. Red Location Cultural Precinct, Phase II: Business Plan, 12.

22 V. Msila, 'The Liberatory Function of a Museum: The Case of New Brighton's Red Location Museum', Anthropologist, 15, 2, 2013, 209-218, 215. For him this can 'sensitise' viewers to the 'sacrifice' for freedom and can lead to an understanding of history and their 'purpose' in that history. Moreover, upon entering this museum, one is overwhelmed by a feeling that 'people have victored [sic] over injustice - at last.' $213-215$.

23 http://www.news24.com/SouthAfrica/News/PE-residents-force-anti-apartheid-museum-to-close-20140731, last accessed 12 October 2016. 


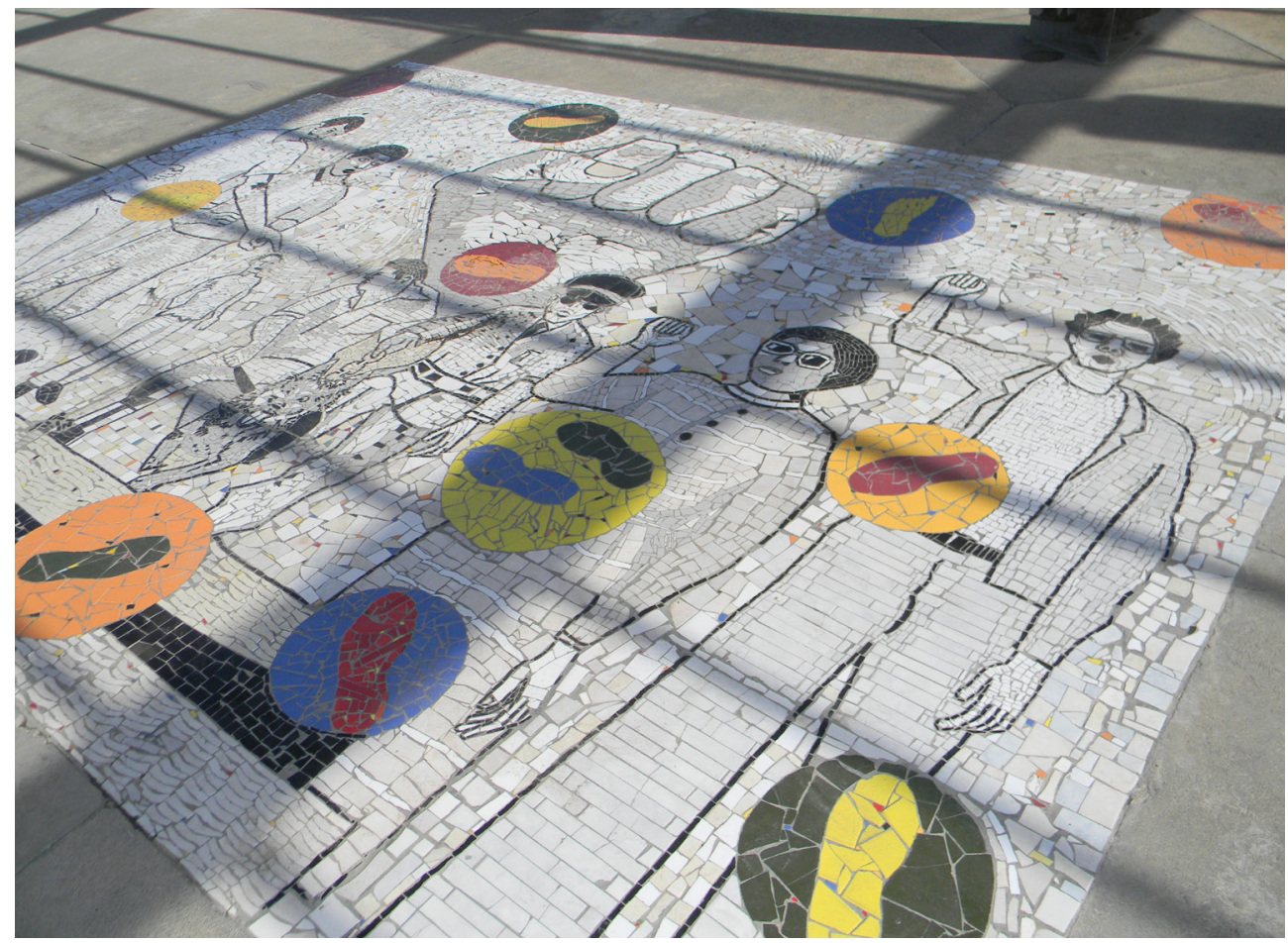

Figure 1: Mosaic outside the Red Location Museum entrance. Photo: Michelle Smith

the museum disrupts the idea that the representation of traumatic memory might lead to some form of catharsis.

This is a very recent encounter between the residents and the museum, but the dispute between the Port Elizabeth Municipality and the Red Location residents, regarding the Cultural Precinct development project, was present even at its conception through numerous protests intended to interrupt the construction of the museum. In 2003 a number of 'community' members were arrested during protests at the building site of the museum, when the residents gathered to articulate their basic need for new housing - not a museum. One of the councillors at the time described these protesters as 'a small group of unruly and ill-disciplined people. ${ }^{24}$ Having started to take apart the museum building, the people of New Brighton have, in a sense, begun to take the idea of this museum to its logical conclusion - decomposition. It was reported that the perimeter fence and palisades of the museum has holes in it, which allow access to the grounds and the roof of the museum building. Some ventilation slats on the outside of the building are broken, giving access to the air-conditioning unit from which copper piping has also been taken. ${ }^{25}$ 
Once you reach the museum building, you are met by a structure which resembles a marquee, constructed of timber, with prominent column-like structures adding to its magnificence and the amount of building materials invested to create a very specific effect. There is a mosaic on the floor (Figure 1) that features some of the symbols associated with being a black subject during the 'struggle' against apartheid. Prominent in the background is a clenched fist, a hand gesture used by anti-apartheid movements during the call-and-response rally cry of 'Amandla! Awethu!' Beneath this fist is an armed policeman with his dog, another figure of oppression, walking among unarmed protestors with their clenched fists in the air. The grey appearance of the background of the mosaic anticipates and prefigures the tone of the blackand-white documentary images and artefacts on display inside the museum, but also doubles the very protests led and held by the New Brighton residents.

The colourful footprints, set against the black-and-white background, invokes the toyi-toyi, a 'movement' of the revolution, whereby protesters would jump and stomp their feet in a rhythmic movement, revolting against racial oppression. However, an alternative reading of this first image at the Red Location Museum becomes imperative, with the increasing revolt against the museum itself by the community. The protests and toyi-toying against the establishment of the Red Location Museum are a performance of the struggle imaged inside the museum mediating the ongoing struggles of the everyday lives of the people who live there. This major architectural project appears here as a symbol of oppression, which 'speaks' through the museumisation of the struggle in New Brighton. It asks that the Red Location Museum face and reflect on its own corrosive potentiality.

\section{Framing Death}

Upon entering the museum building, one is overwhelmed by its high ceiling, an effect created by the rising memorial columns, which tower over the visitor. These columns are dedicated to local heroic figures, like Raymond Mhlaba, ${ }^{26}$ Molly Blackburn, ${ }^{27}$ Ernest Malgas, ${ }^{28}$ Florence Matomela, ${ }^{29}$ Vuyisile Mini, ${ }^{30}$ and others. Black-and-white portraits are boldly titled with the names of the activists and below these are short, typed and dated outlines of each figure's political activities at particular moments of the struggle against apartheid.

The concrete slabs on which these banners hang are a consistent feature of the interior of the museum. According to Christopher du Preez, Acting Assistant Director and Curator at the Red Location Museum, these political figures were chosen by the

26 Raymond Mhlaba was the Secretary of the South African Communist Party's Port Elizabeth branch and a member of the African National Congress (ANC).

27 Molly Blackburn was a chairperson of the Progressive Party in Port Elizabeth, counting as one of the honoured who was not an ANC member. She was very active in investigating 'controversial' police shootings of anti-apartheid activists.

28 The concept of having a museum in Red Location is said to have originated with Ernest Malgas who was an uMkhonto weSizwe (the armed wing of the ANC) soldier, and was imprisoned on Robben Island in 1963.

29 Florence Matomela was one of the women who was arrested during the Defiance Campaign in New Brighton in 1952. She was one of the women at the 1956 Women's March to the Union Buildings in Pretoria.

30 Vuyisile Mini was one of the first ANC members to be executed by the apartheid state. He was a trade unionist and a member of the ANC and its military wing, uMkhonto weSizwe. 
community and a process of alternation was envisaged to include others who are regarded as struggle heroes. This was perhaps a way in which the museum wanted to seek the 'engagement' of the community, a way in which the living could act upon the dead and 'decide' on who haunts them, although the use of cement here gives the impression that something has been set in stone, so to speak. These pillars impose themselves visually, and resemble gravestones in 'a house for dead people', a cemetery, where the prominent leaders are the first to be 'seen. What these 'gravestones' also allude to is that, in a sense, the museum, structurally and conceptually, is built on the bodies of these activists, represented and staged here by their images. It is the imaging of these figures, in the economy of public history and a nationalist narrative, that gives to the museum's representations of the past both legitimacy and legibility as struggle history. Beside the columns, what is visible upon entering are the tall memory boxes, another space marked as 'art gallery', a display of the architectural model of the precinct and a photographic exhibition which can be seen on the wall directly opposite the entrance. ${ }^{31}$

Not all displays are made equal and in the Red Location Museum there are some that remain with you long after you leave the building. These are those displays that visualise death, and although 'struggle' marks the overall narrative constructed by the museum and 'struggle' holds within its meanings a determination to live or alternatively to 'move about violently in an attempt to get free,'32 it is 'death' that haunts both the displays and the museum's relationship to the people for whom it is claimed to have been built.

For the purposes of a discussion around the contestation between the museum and the residents of the Red Location, three exemplary exhibitions offer an image of its framing of the anti-apartheid struggle. As the scope of this article limits a discussion of all of the displays in the Red Location Museum I am forced here to 'frame' this discussion and 'cut' out a number of the other exhibitions inside the museum. There is one photograph in particular which will push the argument of this article in a specific direction in reading the protests in New Brighton. It is the first in the photo essay titled 'You are my witness', which recounts what are, for the narrative preoccupations of the museum, the pivotal parts of the Langa Massacre, exposed through both the conflict and absence of justice in the aftermath of the massacre.

The Langa Massacre occurred on 21 March 1985 on Maduna Road between Langa and Uitenhage, when members of the South African Police Force fired upon a crowd of people. ${ }^{33}$ There were to be no funerals on Saturdays, Sundays, Mondays

31 I did not encounter art exhibitions in the 'art gallery' on my visits to the museum. Instead, the space was used for parts of temporary exhibitions, and was often where the temporary exhibition would start.

32 Collins English Dictionary and Thesaurus (Glasgow: HarperCollins Publishers, 2007), 795

33 The Red Location Cultural Precinct, includes the museum, an art gallery and a library. This grand vision foresaw a visitor who could, once the precinct was completed, '[s]pend time in a museum of the struggle, learning about the times, events and people of the 1980s revolt against apartheid; spend time in an art gallery, appreciating excellent displays of local and South African art and crafts; attend two galleries in a library to see the struggle history of the metropole outlined in a display of books, maps and newspaper articles, and also attend a moving exhibition of books or maps of a particular interest and enjoy public sculpture of an education[al] nature.' This grand vision was supported by a claim that the Red Location was a site of struggle which needed to be celebrated and be historicised as such. This also shows that the curatorial prerogative is framed by the 1980s, where, as I discuss below, the 1985 Langa Massacre frames the struggles which came before it and those which are present for the people of New Brighton. Cultural Precinct Phase 2: Business Plan, 127. 
and public holidays by order of a ban issued under the Internal Security Act. This was to curb attendance at funerals since the police feared that these gatherings were an opportunity for political rallying. The funeral held on that day was to bury several young men who had been killed by the police some days earlier. Ignoring the order, people gathered to walk to the funeral. The massacre on Maduna Road took the lives of 20 people, with several others injured. ${ }^{34}$ The exhibition is initiated with a road sign, indicating that the massacre occurred on Maduna Road and directs the visitor towards the first image, which is also the title of the exhibition, 'You are my witness', with an inscription above it that reads as follows: 'A photographic essay and commentary dedicated to the mothers, fathers, women, men and children of the Langa Massacre, Uitenhage, who sacrificed their lives for the liberation struggle of South Africa. A dedication to those who continue to define their paths as survivors of such brutal carnage. ${ }^{35}$ This title and inscription is placed above an image of mourners, standing around uncovered graves - 'unmarked' in this photograph - with raised fists, similar to those depicted in the mosaic on the outside of the museum's entrance. This is also the last image in the photo essay. The enlarged prints are arranged along the walls surrounding the memory boxes and are seemingly self-contained because of the concrete slabs that separate and 'frame' them. Each image is accompanied by a caption and, in the case of some of the images, an inscription printed onto the wall below it. The captions do not mention the photographer, but give a brief, two-line description of what the visitor is 'seeing'.

The text below the images gives historical context, situating this event, the Langa Massacre, within a wider narrative of state oppression. ${ }^{36}$ This is made possible by photographs of a number of immediately recognisable, iconic symbols: coffins carried by bearers with raised fists (funeral processions), a street in the township showing ghastly living conditions, armed police squads, 'hippo' armoured vehicles and political leaders. The apparent function of the exhibition is to expose the lies of the distorted findings of the Kannemeyer Commission by exhibiting the findings of this report and contrasting it with the final report of the Truth and Reconciliation Commission and the testaments of the survivors of the massacre. These testaments are followed by a collage of portraits of survivors and witnesses. Concluding the exhibition is a repetition of the image of mourners around open graves. While the narrative of the massacre is told through various photographs, they are 'framed' or, rather, enclosed at both ends, by the open grave photograph which appears at the beginning and the end of the photographic essay. Thus, regardless of where the viewer starts her viewing, the image of the open grave is the first and last image seen.

34 R. J. Thornton, 'The Shooting at Uitenhage, South Africa, 1985: The context and interpretations of violence', reprinted from American Ethnologist, 17, 2, May 1990.

35 The term 'victim' was strongly rejected during and after the Truth and Reconciliation Commission proceedings on account of implying passivity and instead 'survivor' is chosen because it connotes political agency. See A. Feldman, 'Memory Theatres, Virtual Witnessing, and the Trauma-Aesthetic', Biography 27, 1, Winter 2004, 178-179.

36 In similar ways to lighting, labels and texts in exhibitions do much to give visual direction to the viewer and 'convey referential content, present and explain concepts, categories, themes, and other information that define an interpretive framework and help create rhetorics of value'. In C.A. Kratz, 'Rhetorics of Value: Constituting Worth and Meaning through Cultural Display', Visual Anthropology Review, 27, 1, Spring 2011, 35. 
After 'You are my Witness', the next photograph is of the coffins being carried by bearers through a large crowd, with raised clenched fists, captioned 'Funeral procession on 14 April 1985 - Uitenhage.' It is with this image that the textual description of the event starts and not with the first photograph, 'You are my Witness', which is made to stand on its own, not needing context, whether in the local or national struggle. It is this photograph that does the work of positioning this event within a larger, national struggle narrative, framing and containing the other exhibitions. Writing about the Apartheid Museum at Gold Reef City just outside Johannesburg and the Hector Pieterson Museum in Soweto, Darren Newbury shows how, at these 'struggle museums', photographs are enlarged and displayed 'unframed' on the museum walls. Expanding on further aspects of these displays, he writes:

The faith in photography as a means of telling the truth about society, the emotional and moral appeal to the viewer, the idea of the photographer as witness and the twin focus on the lives of "ordinary" people and major political events are all aspects of these museum displays. The displays draw visually on photographic modernism with an emphasis on reproducibility and the manipulation of size...The particular contexts within which photographs were originally made and shown are subservient to an overall message, one that is characterized by reconciliation, a sense of hope for the future and faith in humanity. ${ }^{37}$

This reading offers insight into the framing image at Red Location. In the centre of the photograph are the open graves and the raised fists of the mourners, providing a figure from whom the words 'You are my Witness' are perhaps meant to come, the viewer/visitor hailed as witness. Although this is a tightly framed photograph - the bodies of most of the mourners in the frame are in a sense 'cut off' - this does not dissuade from the effect of a larger presence of mourners, an effect created by their proximity to the graves and their proximity to each other. The mourners are also faceless in their representation in the image, constituted as the mass struggle subject, while individual portraits are reserved for 'struggle heroes' and, in this photo essay, for the survivors of the massacre.

'You are my Witness'. Are these the words of the mourners? Are they the words of the dead? Or does the interpellation come from somewhere else entirely? This photograph appears without any inscription and is instead left 'open' to interpretation, as open as the open graves. The grave suggests the violence that preceded it; thus, in this photo essay it is death that is imaged first, at least the suggestion of death, and what follows is the imaging of the narrative that both begins and ends with graves waiting for the dead. 'You are my Witness', an over-determined phrase offering various routes that lead towards the display, mourning and celebrating those lost in the struggle. Those who struggled are now dead, but, in preparing a place for them in the grave

37 D. Newbury, "Lest we forget": Photography and the presentation of history at the Apartheid Museum, Gold Reef City, and the Hector Pieterson Museum, Soweto', Visual Communication, 4, September 2005, 287. 
and in the frame of the photograph, they will not be forgotten. The unmarked, open graves in the first photograph, 'You are my Witness', and its location, framing the displays in the memory boxes, creates another effect of transformation, which in its inclusion of the poverty of the community into the struggle narrative of the museum, has a mortifying effect. At the end of the photo essay, there is no resolution; the dead are still dead. The community's grievances are foreshadowed here. If the struggle continues in the present, if the residents of New Brighton are represented as the figures of contemporary struggle, is the place prepared for them within this narrative a grave?

Useful here is the way in which John Tagg brings into relief the materiality of the image - how it is itself subject to decomposition - and our changing relationship to that which is imaged. For Tagg, it is the frame that produces a loss of a sense of the materiality of a photograph and it is here 'under the protection of the frame' that our attention is 'pulled back into the imaginary'. He calls these the two worlds created by the photograph and the encounter with it - that of the material and the imaginary. Tagg goes on to suggest that it is between these two worlds that the meaning of this encounter between the photograph itself and the viewer is hedged. But the impossible juncture' of the material and the imaginary is, although produced by the frame, also 'masked' by it; we know the frame is there but we disavow it. ${ }^{38}$

Through curatorial imperatives and exhibition space, the photograph is used to represent particular truths about the past, even though such truths are impossible to know. Tagg leads us towards thinking of the use of the 'struggle image' in the museum and our relationship to that to which we are called to bear witness. Moreover, is there a relationship here between the truth effect of the image and the historical function of the 'struggle image' to expose lies, to reveal the truth and its place in the museum now? Does the photograph, and specifically struggle photography in the Red Location Museum, take the place of the dead body? The materiality of the scene of mourning imaged is doubled in the materiality of the image itself; the decomposition of the corpses we cannot see in the open graves are constantly recalled by the decomposition of the photograph, knowledge of which is disavowed through the frame. Reading with Tagg, the statement, 'You are my Witness', unstable and overdetermined, left open, asks us to pay attention to the materiality of death in the history of New Brighton, specifically black death, concealed in and through the frame of this exhibition. While it is, of course, impossible to fix the speaker of the statement 'You are my Witness' and the addressee to whom it is spoken to say once and for all who this actually refers to, Tagg asks us to attend to the process of disavowal at work in this image that encloses this exhibition and frames others in the museum. Bearing this framing in mind, he asks us to attend to the 'community'; life in the township, both inside and outside the museum, is framed with an exhibition of the interior of a shack, and the shack installations outside the museum.

38 J. Tagg, The Disciplinary Frame: Photographic Truths and the Capture of Meaning (Minneapolis: University of Minnesota Press, 2009), 3-5. 


\section{Entering Empty Graves}

Near the entrance of the museum is a closed off exhibition space. On my first visit there, the room was occupied by replicas of former President Mandela's diaries and correspondence. The museum was not able to display the original documents because of inadequate temperature control facilities. ${ }^{39}$ On my next visit this exhibition had been taken down, and the space was empty, except for a sound-proof door that lead into a kind of 'chamber.' Inside were remnants of what was intended to be a tomb which would keep the remains of Govan Mbeki and Raymond Mhlaba. ${ }^{40}$

According to Christopher Du Preez - the curator and head of the museum - the architect, Joe Noero, was instructed by the Executive Mayor to add a space on the inside of the building for the reburial of Mbeki and Mhlaba, thus 'sacrificing a crucial area intended for object storage and part of the museum restaurant."11 As expected, there was some controversy around this tomb, which did not materialise after an intervention by former president Thabo Mbeki, the son of Govan Mbeki. The reburial of Mhlaba and Mbeki was intended to coincide with the opening of the museum, but Mbeki had wanted to be buried next to the people he served, in the Veeplaas cemetery where, after his death, Mhlaba was laid to rest next to him. ${ }^{42}$ Du Preez rightly points out that beside the fact that the architect and the Mayor wanted this to be a space of reflection and quiet, which would have been in direct contrast to interactive curatorial objectives of the museum, it is also a time of great debate and contestation over human remains in museums. ${ }^{43}$ The history of museums in South Africa is haunted by the collection and display of human remains where 'skulls, skeletons, and plaster casts were indeed the museum "alternatives" to the objectification and dehumanisation involved in the display of live Bushmen."

Up until the closure of the museum, and perhaps still at this time, instead of their remains, there are two enlarged photographs of Mhlaba and Mbeki leaning against the walls of the tomblike space. Figure 2 shows the photograph of Govan Mbeki, with its reflection appearing inside the tomb. Indeed, the photograph is made to stand in the place of the body.

The Vuyisile Mini installation, also located in a memory box is dedicated to local uMkhonto weSizwe soldiers who were executed during apartheid. Upon walking into the memory box, one is greeted by an almost floor-to-ceiling, black-andwhite portrait of Mini. The effect makes him into a giant to look up to. From the

The walls of the Red Location capture moisture and as a result are often damp, sub-optimal conditions for the display of these documents. As a consequence, the small collection that they do have is kept in Bay Museum's storage room.

40 Govan Mbeki was the chairman of the Eastern Cape branch of the ANC, and an active member of the South African Communist Party (SACP), who was involved in the armed struggle against apartheid. Raymond Mhlaba was the Secretary of the SACP's Port Elizabeth branch and a member of the ANC. Both of these leaders were Rivonia Trialists; a trial which saw many of South Africa's liberation leaders imprisoned on Robben Island in Cape Town.

41 Du Preez, 'The Role of Architecture', 2.

42 M. Jack, 'Oom Gov to remain at Veeplaas Cemetery', The Herald, 19 April 2005.

43 Du Preez, 'The Role of Architecture', 5.

44 M. Legassick and C. Rassool, Skeletons in the Cupboard: South African museums and the trade in human remains, $1907-1917$ (Iziko Museums of South Africa, 2015), 5. 


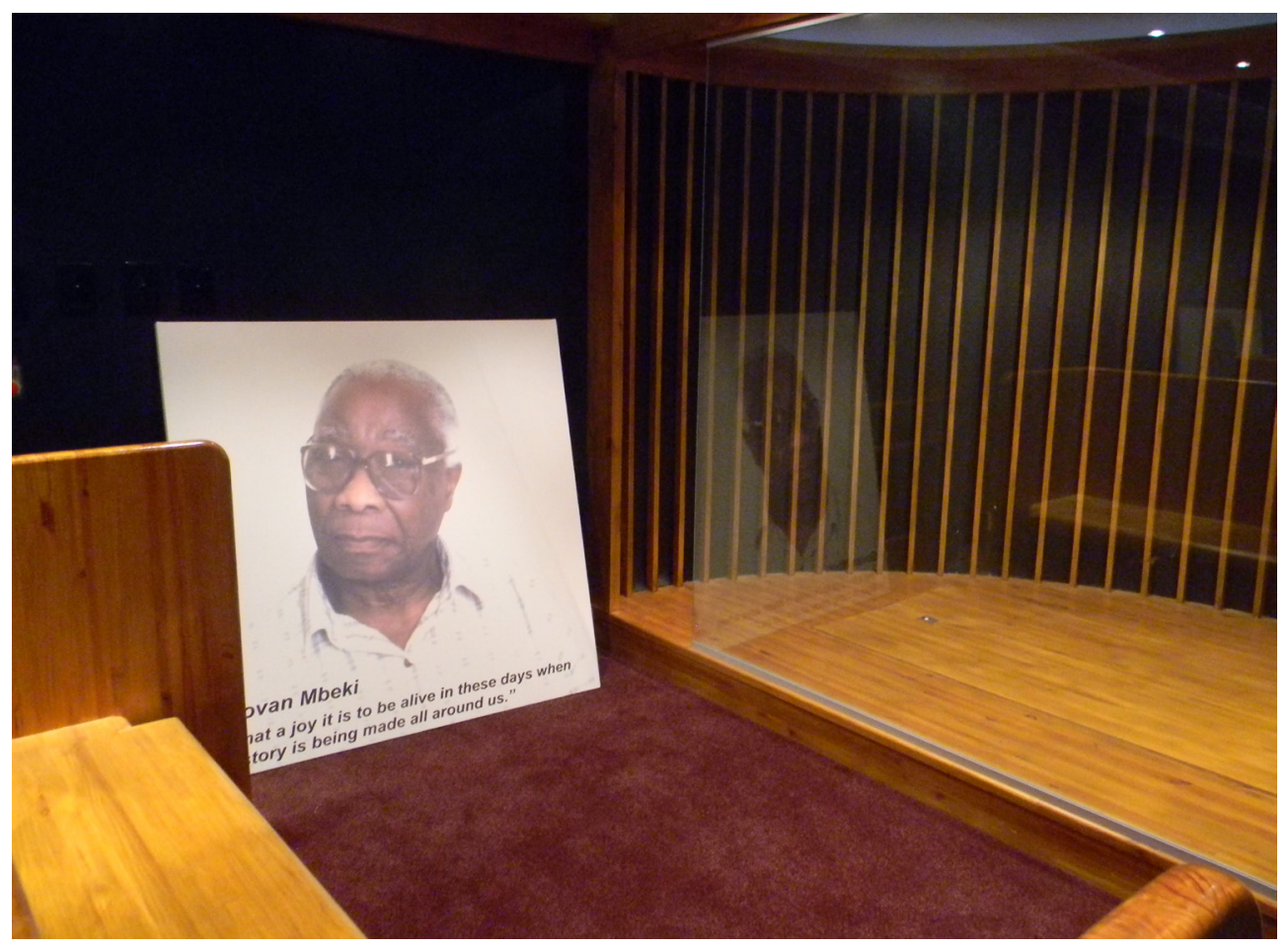

Figure 2: Impression of photograph of Govan Mbeki in the tomb at the Red Location $\mathrm{Mu}-$ seum. Photo: Michelle Smith

ceiling hang three nooses, representing the executions of Mini and two other activists, Wilson Khayinga and Zinakile Mkhaba, who were executed under the Terrorism Act in March of $1964 .{ }^{45}$ Arranged along the walls from floor to ceiling are filing boxes, representing all those who died at the hands of the Security Police and the South African Police during apartheid. A tag is pasted onto each of them, with three categories indicating a person's name, cause of death and the findings of inquests into their deaths. One does not notice this immediately, but the majority of the boxes have no name; in fact, none of the categories are announced, pointing towards those who went missing and whose bodies were never found. Some indicate that a dead body was found but that the bodies were never identified. For the many names that are given, one is struck that no one was ever found liable for their deaths.

Standing in the memory box, gazing up at Minis portrait and overwhelmed by 'dead bodies' one hears a voice - the recording is set off when one enters into the memory box - narrating Mini's defiant words before he was executed. The voice explains that the three men sang one of Mini's beloved protest songs. A choir starts to sing the song and it completes the effect of the 'installation'. The immediate effect of 
the portrait is powerful in its agency and individuality, in stark contrast to the near anonymity of many of those who died during apartheid, his singular image - modern and urban in his tailored suit, his thoughtful hand gesture, his direct gaze at the camera and the viewer - set against a mass grave.

However, this image of Mini is not a lone shot of a prominent leader. In the original photograph he is in fact seated next to three other activists and this photograph was taken in an alleyway, the four figures shouldered on either side by brick walls. This is also 'cut out' of the representation of Mini in this memory box. This image of Mini was used in other contexts during the struggle, although mostly these were head-and-shoulder renderings with Mini's body 'cut out'. For this installation and in this 'house for dead people', the presence of Mini's body in the photograph is crucial. This process of cutting and cropping is not made known in the display, creating tension with the purpose of the documentary image, which is to expose violence, making this practice of cutting violent in itself.

\section{The Inside-of-the-Outside}

Two shack installations enter the New Brighton community into the empty graves. As discussed above, one is located inside the museum in one of the memory boxes, the other next to the front entrance of the precinct gallery (Figure 3). In other words, in the museum narrative of struggle against apartheid, labour exploitation and violence on the black body, it is the community's struggle against poverty that is on display here. The over-determined photograph of the open graves in 'You are my Witness' allows for this struggle to be inserted into the visual regime of the 'house for dead people. This is despite the museum's intentions of producing these installations in order, as Chris du Preez put it, 'to debunk the notion of townships as spaces for romanticised representations of suffering and spectacle. 46

The shack installation, or 'imitation' as described by du Preez, 'was done deliberately to divert foreign tourists looking for an "authentic" experience, from constantly invading the privacy of people's homes opposite the museum. ${ }^{37}$ The 'imitation' shack provides 'an "authentic" experience' that diverts attention away from 'people's homes. ${ }^{48}$ It also, however, results in a kind of commercialisation of 'the shack' as exotic object, an 'imitation' that is almost more 'authentic' than the actual living conditions of the people outside. An erasure of the everyday by something 'other', even archetypal, typified as representative of how 'any shack' would look. So although the individual yields power in the museum narrative of the struggle, here there is a particular aestheticisation of the living conditions of the poor. The tourist/viewer can come and see - indeed, scrutinise - shacks inside the museum so that they - despite attempts to 'divert' the tourist gaze, and perhaps precisely because of this - overlook those on the outside, rendering the community both invisible and hypervisible. Sight 


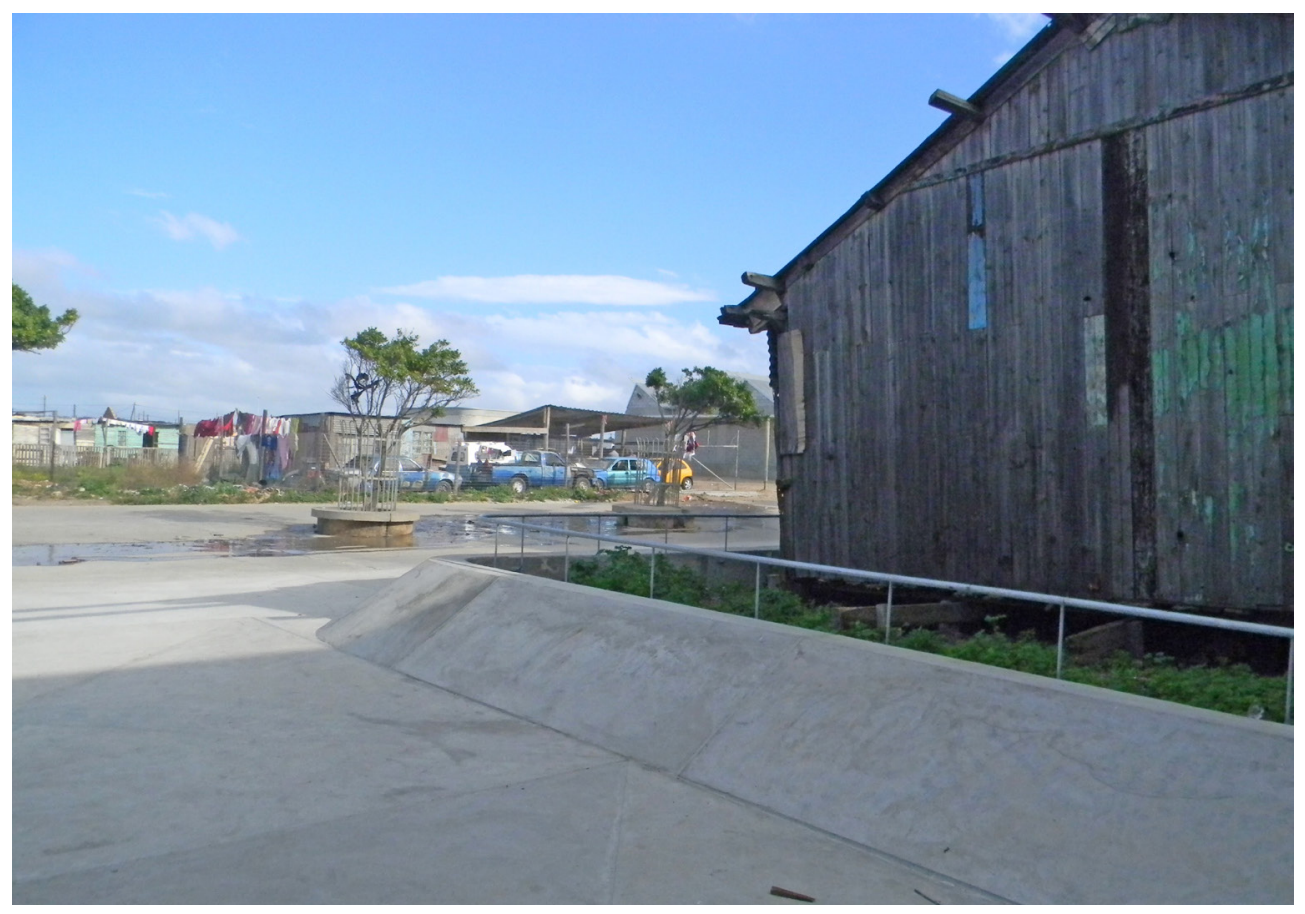

Figure 3: The installation in front of the Red Location Art Gallery and the homes of the residents. Photo: Michelle Smith

and site are thus configured in terms of this deadening of the 'community', ironically through this close proximity between the museum, and the residents and their shacks.

The shack positioned in front of the precinct art gallery was previously occupied by Themba Adams, a 36-year-old man from New Brighton, who was surprised to see the shack that he grew up in displayed in this way. He tried to move back into it with his belongings in hand, but was turned away. ${ }^{49}$ This dramatises the stakes of building a museum in Red Location. What functions as a divide between the inside and the outside, the concrete walls of the museum, which are meant to be impermeable, are in fact exposed as implicitly porous. The walls - barriers between the community, and the museum and its objects, between past struggles and the present, between the living and the dead - were always already decomposing.

The precinct initially had four 'historic cottages', one of which was destroyed by gale force winds, indicating how fragile and vulnerable shacks are to the elements. It was reported that 'vandals' were 'stealing' and stripping materials from these constructions, which were seen as part of the heritage of the Red Location..$^{50}$ In 2009,

49 Adams was jailed in 2008 and on his release in 2012 he travelled to East London, in the Eastern Cape. He returned to New Brighton in 2014 to live where he had always lived, but his shack had been in the vicinity of the area that had to be cleared for the cultural precinct building to commence and is, according to the museum, a valuable artefact. Y. Sobuwasobuway, 'Homeless man wants his shack back from museum', The Herald. 12 September 2014.

50 N. Sonjica, 'Scrapyards benefit as Red Location materials are carried away', The Herald, 15 July 2008. 
a decision was made to preserve these cottages along with the development of the precinct with Phase Two, which included the construction of the art gallery, the municipality declaring that 'those three will definitely not be demolished because they form part of the history of the area and of the Red Location museum as well. ${ }^{51}$

Figure 3 shows the 'scene,' the visual landscape, against which this 'artefact' is staged. When standing at the door of the art gallery you can see both the installation of the shack and the homes, the shacks, of the people that surround it. As mentioned above, the other shack displayed is inside the museum. Here, the shack is the memory box, the corrugated iron walls of the memory box used as those of the shack walls.

\section{The Death of Red Location Museum}

Red Location Museum has not staged this porousness between the inside and the outside of the museum - and between past and present, the real and the simulated, the living and the dead - as a problem for the museum and the community to work out and think through together. In this final section I want to place what I take to be a question at the heart of Red within Red Location Museum's mortificationary complex, but this will be an encounter that will not leave Red, itself, unmarked.

The Ann Bryant Gallery in East London, a large old house built in 1905, is quite the opposite of the industrial, factory-styled Red Location Museum; it conjures not working-class subjects, but upper-class East Londoners of this time. One enters the front of the house after crossing a large garden and walking up a red exterior stairway. The red-roofed house has a number of large rooms, which are now used for art exhibitions, and the second floor is made available for conferences and workshops. It was on the first floor that you encountered Red, a sparse display of the car parts of the Red Mandela Mercedes-Benz 500SE. The bonnet of the car was displayed as you entered the house from the back (it would seem that this access point was used by the gallery as its entrance); the 'uniforms' (made from the materials of the car seats) and the 'beds' (created out of scaffolding and bent-out-of-shape mattresses) were all displayed in different rooms. The viewer was never presented with a complete object, as opposed to the exhibition of the 'authentic' Mandela Mercedes-Benz at the Apartheid Museum, where it is displayed 'whole.'

When people mourn, in the absence of tangible remains, some substitute object often offers a 'corporeal presence' that mediates this absence. ${ }^{52}$ At the Apartheid Museum, the 'original' Mandela Mercedes is arguably deployed to do precisely this, forming part of a narrative of one man's struggle, that of Nelson Mandela. While some may argue that Red, too, relies on the aestheticisation of death - in ways similar to the Langa Massacre exhibition in the Red Location Museum - it also works to critically resist particular narrativisations of the struggle against apartheid. That is, it participates in this substitution only to take it apart, interrupting or disassembling

51 T. Jijana, 'Red Location shacks to be preserved', The Herald, 6 January 2009.

52 M. Sturken, 'The Aesthetics of Absence: Rebuilding Ground Zero', American Ethnologist, 31, 3, $2004,312-113$. 
the tightly crafted narrative of which the 'original' car forms part, inside the Apartheid Museum.

The master-narrative of the apartheid past, in museums, relies on the image of death, specifically the death of the black subject of apartheid, and the ways in which it has been figured in the South African Truth and Reconciliation Commission's (TRC) inquiry and report. This report also informs the Langa Massacre exhibition in content and, conceptually, the way in which the photograph is mobilised to expose the lies about the apartheid inquiry into the massacre. A part of the TRC's role, to 'help deal with what happened under apartheid, ${ }^{53}$ was reparation - often in the form of exhumation, reburials and ceremonies of mourning. For the Commission, public rituals of mourning gave the 'nation an inheritance that is recoverable, containable and ultimately buriable as the markings of history. ${ }^{34}$ It is through the presentation and the visuality of the body that the apartheid past becomes measurable and finite, 'allowing for the final fatality of apartheid and a rebirth at the threshold of a new nation out of "exquisite cruelty"” ${ }^{55}$ Museums such as the Red Location and the Apartheid Museum take their cue from the TRC, acting as sites of public mourning. By contrast, Gush produces the body the nation would make whole again - if only symbolically, as with the original Mandela Mercedes in the Apartheid Museum - as being, still or again, in pieces; he provides a substitute only to disassemble it. ${ }^{56}$

In proposing the car as a substitute object, it is worth recalling that cameras and cars share not only a moment of technological emergence, but a memorialising function, each an archival apparatus. ${ }^{57}$ But while automobiles are receptive to impressions, to exposure - one might even say they have a photosensitive surface of inscription, sensitive to light - they have no means to process these impressions, their latent images. Nonetheless, a core function of these machines may be an archival one: the automobile as a technology of memory. At least, there was in this particular automobile an inscription entrusted to a particular recipient, Nelson Mandela. As he read it - at least as he led those who gave it to him to understand how he read it - the red Mercedes was a testament to those who struggled for the freedom of South Africa, to the blood that had been spilled. He read it, thus, as an encryption, an engraving. Now that he, too, has passed away, the archival automobile stands as a testament to his life of struggle. The inscription by the workers holds the possibility of including itself, the very labour of assembling a struggle archival automobile, becoming a kind of struggle in its own right. ${ }^{58}$

53

54 C. Rassool, L. Witz, G. Minkley, 'Burying and Memorialising and L. Van de Vijver (eds), After the TRC: Reflections on Truth and Reconciliation in South Africa (Athens: Ohio University Press, 2001), 11.

55 Ibid.

56 On the significance of graves in public and visual history, see D. Bunn, 'The Sleep of the Brave: Graves as Sites and Signs in the Colonial Eastern Cape, in P. Landau and D. Kaspian (eds), Images and Empires: Visuality in Colonial and Postcolonial Africa (University of California Press, 2002), 56-57.

57 Each also acts as a frame through which the world is perceived, lighting up what is before it, each a protective shield against the world, absorbing shock, a mechanical membrane, a skin through which objects and others are mediated. Though I write under the influence of Walter Benjamin here (see Illuminations, 175-176), both cars and cameras were surely, at the time he wrote, a part of the shock of modern life. Perhaps for this reason Benjamin was a flâneur, walking rather than driving, the city.

58

If my reading of Red Location carries any weight, then this struggle bears a wager of death. 
In the Red Location Museum as a 'house for dead people', a tomb or graveyard, the photographic image both invokes the death of the black body and comes to stand in for it. The museum not only has a proximity to the residents, the people of New Brighton, it also creates a proximity to the past, through the image. For the residents who protest against the establishment of the Red Location Museum, the museum is the grave; the photograph, the decomposing body. ${ }^{59}$ The Red Location community's articulated cry against a process of mortification by the museum is communicated strongly through various actions that are understood and represented by museum officials and the media as 'stealing', 'ill-discipline', 'vandalism', and so on. But I want to suggest that the residents are rather exercising, in a sense, an aesthetic judgment informed by the politics of representation and subjection.

Placing Red alongside the Red Location Museum offers an opportunity to think again about the ways in which historical narratives produce subjects of struggle. I want to suggest that such rethinking takes place between the resistance of the residents of New Brighton and the car-body in pieces outside the Anne Bryant Gallery. Between because, although not symmetrical, these two scenes can be superimposed: preserved on the outside of the Red Location Museum is the red corrugated iron shack, suspended - much like the red car-body or frame that was curated outside the gallery building - between the past and the present. But if this is what Red does, calls into question that which is inside the museum, the residents of the Red Location call into question the structure itself, the frame. I want to argue then that there is a difference of strategy at work here between Red and Red Location.

Bringing Red to bear on the mortificationary effects of the frame as it is put to work in the Red Location museum, we are asked to think differently about the postapartheid. Red narrates a connection between the failed strike at the Mercedes-Benz factory and the release of Nelson Mandela. If the present was stillborn, born dead, and death animates both the struggle against apartheid and the commemoration of that struggle, Red - placing as it does one of the earliest acts of post-apartheid commemoration within its frame - is not left unmarked by its encounter with the Red Location Museum, a ruin, a dead building, a decomposing frame. ${ }^{60}$ Placed alongside the Red Location Museum, the car built to commemorate the release of Nelson Mandela appears to be carried like a coffin during its process of assemblage, its colour, red, given meaning as symbolic of the lives lost during the struggle. The whole scene of this moment at which the birth of the new nation is 'seen' to emerge is marked by death, at least in commemorative museums of the struggle. Red then offers itself as a latent image of commemoration, showing how the 'house of the dead' is in turn framed by an historical moment, the gifting of a red Mercedes-Benz; this latent image appears

A. Bazin, 'The Ontology of the Photographic Image', Film Quarterly, 13, 4, Summer 1960, 8. Bazin writes: 'Only a photographic lens can give us the kind of image of the object that is capable of satisfying the deep need man has to substitute for it something more than a mere approximation, a kind of decal or transfer. The photographic image is the object itself, the object freed from the conditions of time and space that govern it. No matter how fuzzy, distorted, or discoloured, no matter how lacking, in documentary value the image may be, it shares, by virtue of the very process of its becoming, the being of the model of which it is the reproduction; it is the model.'

My thanks to one of the anonymous reviewers of this article in draft form who referred to the museum as a 'ruin, a dead building. 
here at the scene of resistance of the residents against the mortificationary logic of the museum.

The museum's acting assistant director expressed relief that 'the thieves have not yet laid their hands on important and valuable documents, files and other materials inside or on display inside the museum. ${ }^{61}$ But this taking apart and carrying away of the 'frame' of the building, rather than the contents of the museum, is perhaps the way in which the residents give meaning to their resistance and struggle against this process of mortification, of being entered into open graves. What the museum was trying (but failing) to contain since its inception is the resistance of the people of Red Location against this house for the dead, but the residents have found a way of disassembling the museum, which resists the disavowal of the frame by taking it apart and leaving the contents, the displays. The museum, and the rest of the precinct, is still closed, with a warning sign to those who might want to enter without the permission and presence of a New Brighton resident. However, the residents' 'threats to assault visitors' who try to visit the museum - and what appears to be a fundamental question for them, namely 'why build a house for dead people when us the living do not have a roof over our heads?'62 - considered alongside the installation of Red at the Ann Bryant Gallery pushes us to think of the museum or gallery as an apparatus and asks for public history, the place of the museum, and the use of images in institutions like museums, to be taken seriously, again. My argument, then, is that Red Location Museum is re-framed from the outside, although an outside that might otherwise belong inside the Red Location Museum.

61 http://www.news24.com/SouthAfrica/News/PE-residents-force-anti-apartheid-museum-to-close-20140731, last accessed 12 October 2016.

62 Ibid. 